Série Informação para ação na Covid-19
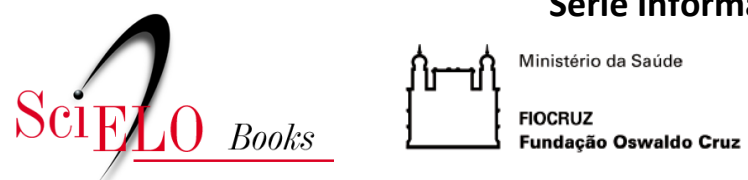

OBSERVATÓRIO COVID-19

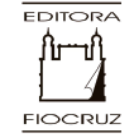

Parte I - Enfrentamento da covid-19 no âmbito Nacional e internacional

\title{
1. Pandemia de Covid-19: por que devemos olhar para o contexto internacional? Reflexões sobre a governança do setor Saúde
}

\section{Celia Almeida}

\section{SciELO Books / SciELO Livros / SciELO Libros}

ALMEIDA, C. Pandemia de Covid-19: por que devemos olhar para o contexto internacional? Reflexões sobre a governança do setor Saúde. In: PORTELA, M. C., REIS, L. G. C., and LIMA, S. M. L., eds. Covid-19: desafios para a organização e repercussões nos sistemas e serviços de saúde [online]. Rio de Janeiro: Observatório Covid-19 Fiocruz, Editora Fiocruz, 2022, pp. 37-62. Informação para ação na Covid-19 series. ISBN: 978-65-5708-123-5. https://doi.org/10.7476/9786557081587.0002.

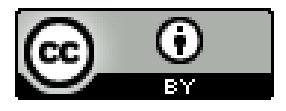

All the contents of this work, except where otherwise noted, is licensed under a Creative Commons Attribution 4.0 International license.

Todo o conteúdo deste trabalho, exceto quando houver ressalva, é publicado sob a licença Creative Commons Atribição 4.0.

Todo el contenido de esta obra, excepto donde se indique lo contrario, está bajo licencia de la licencia Creative Commons Reconocimento 4.0. 


\section{Pandemia de Covid-19}

\section{por que devemos olhar para o contexto internacional? Reflexões sobre a governança do setor Saúde ${ }^{1}$}

Celia Almeida

esde o início de 2020 vivemos uma situação inusitada com a pandemia de Covid- I 9 e seu impacto em todos os âmbitos da vida cotidiana, em todos os níveis - mundial, nacional, grupal e individual - onde a incerteza e a insegurança parecem permanentes.

Mais do que nunca, precisamos estar atentos às várias dimensões interconectadas desse processo. Muitas dinâmicas complexas que já estavam em curso se exacerbaram e ficaram mais visíveis com esta catástrofe humanitária, que não foi produzida só pelo vírus até então desconhecido, mas por todo contexto global, multifacetado e agressivo do qual ele emana.

Hoje sabemos mais sobre o vírus, graças a um historicamente inédito e rápido desenvolvimento científico e tecnológico. Sabemos, teoricamente, o que se deve (ou deveria) fazer e o que pode (ou poderia) ainda ser feito. Proliferam recomendações, sugestões de procedimentos/alianças que poderiam ser adotadas, com melhores possivelmente resultados. Por que não se cumprem, ou não são alcançados os benefícios que apregoam?

Para além das fronteiras nacionais, e sem diminuir em nada a inadmissível irresponsabilidade de alguns governantes, parece-nos importante olhar um pouco mais além. Existem conexões entre os contextos internacional e nacional que merecem nossa atenção.

Constata-se a simultaneidade de mudanças que vinham ocorrendo no mundo desde os anos 1990, e discussões sobre a área social, incluída a saúde, pari passu com o surgimento dos novos termos - saúde global, diplomacia da ou em saúde global, governança da saúde global. Aquelas mudanças alteravam a dinâmica do sistema mundial, composto pelos Estados-nação em um mundo caracterizado por grandes assimetrias de poder (centro, periferia e semiperiferia) e do sistema internacional, formado pelo

\footnotetext{
I Síntese atualizada de trabalhos publicados pela autora em 2020 e 2021.
} 
conjunto de instituições e organizações multilaterais - a Organização das Nações Unidas (ONU), as instituições resultantes dos acordos de Bretton Woods (Fundo Monetário Internacional, Banco Mundial, Banco Interamericano de Desenvolvimento etc.) e outros grupos multiestatais -, assim como as relações entre diferentes atores (antigos e novos) nas arenas internacionais, repercutindo de forma relevante nas políticas nacionais em todos os setores.

Algumas perguntas se sobrepõem: por que as respostas nacionais e regionais são tão diferentes, para além dos respectivos contextos e conjunturas específicas e dos regimes políticos em cada país? Por que as organizações multilaterais têm sido tão criticadas há décadas, especialmente a Organização Mundial da Saúde (OMS)? Por que as disputas globais por insumos essenciais aos cuidados em saúde são tão acirradas (p. ex., a "corrida” por equipamentos de proteção individual (EPIs), por respiradores e pelas vacinas, atualmente a ponta mais visível desse iceberg)?

Não temos respostas fáceis ou completas para essas perguntas complexas, pois são muitas as variáveis envolvidas e tampouco existe uma única resposta para qualquer pergunta. A forma como olhamos para determinada questão varia segundo os diferentes pontos de vista que adotamos para a nossa reflexão, que podem ser complementares ou até antagônicos. Portanto, nossas "respostas" serão seletivas e necessariamente parciais.

A proposta neste texto é explorar elementos que nos ajudem a refletir sobre algumas dessas perguntas. Adotamos as perspectivas da economia política internacional e da formulação/implementação de políticas, com foco na dinâmica global. As reflexões apresentadas se baseiam em revisão bibliográfica e análise documental.

\section{ORDEM INTERNACIONAL INCERTA E CRISE DO MULTILATERALISMO}

A ordem mundial pode ser definida com base nas características institucionais e normativas que condicionam os mecanismos de cooperação, concorrência e conflito no sistema interestatal. Foi reestruturada em diferentes momentos históricos, consolidando a acumulação capitalista.

Multilateralismo e ordem mundial são inter-relacionados: o primeiro é uma força ativa e não pode ser desvinculado do contexto histórico em que ocorre, isto é, do contexto que molda a estrutura da ordem mundial. O "termo multilateral incorpora pelo menos dois significados - um relacionado às relações interestatais e outro às relações entre variados atores - públicos, privados e da sociedade civil", [portanto] "é necessário analisá-lo na perspectiva das relações de poder que movem o sistema mundial” (Almeida E Campos, 2020: 15). 
O contexto específico do surgimento do multilateralismo contemporâneo remonta ao pós-guerra e, nele, duas dimensões são relevantes: a econômica e a política. As inflexões e mudanças de rota na dinâmica da ordem mundial, e consequentemente do multilateralismo, foram profundas e significativas desde então. Em termos muito sintéticos, na dimensão econômica o consenso provisório da ordem mundial liberal lançou as bases para a expansão do capitalismo, e na dimensão política institucionalizou os arranjos necessários, materializados no sistema internacional (Almeida $\mathcal{E}$ Campos, 2020).

As atribulações econômicas dos anos 1970 e o fim da bipolaridade alteraram a ordem mundial liberal no pós-guerra fria (1 990 em diante) e evidenciaram as estratégias unilaterais do hegemon (EUA), extremamente bélicas e intervencionistas, ampliando de forma importante o "poder imperial” norte-americano (Fiori, 2020).

Concomitantemente, o ideário econômico e político-ideológico neoliberal, descartado no imediato pós-guerra, retomou protagonismo em nível global, sob a liderança do Fundo Monetário Internacional e do Banco Mundial, materializado nos ajustes macroeconômicos, que promoveram também o desmonte das políticas sociais, incluídas as de saúde (Almeida E Campos, 2020). Uma agenda de reorganização dos serviços de saúde se difundiu mundo afora, estimulando as controvérsias e as reformas "pós-welfare". O rastro global de destruição desse processo é bem conhecido: aumento exponencial das desigualdades e iniquidades (entre países e dentro de um mesmo país), da extrema pobreza e das migrações (sul-norte, norte-norte e sul-sul). Registra-se também a concentração, cada vez maior, da produção de insumos (variados e necessários para o cuidado em saúde) em empresas nacionais/multinacionais, em um primeiro momento, e transnacionais e desterritorializadas, logo em seguida.

Em resumo, com o desaparecimento do regime geopolítico bipolar, alteraramse também os princípios éticos e político-ideológicos que sustentavam as relações no sistema interestatal, como a cooperação entre as grandes potências capitalistas, anunciando que estávamos entrando em um período de transição para uma "ordem mundial incerta”, encoberta pelo entusiasmo que despertou a ideologia da globalização neoliberal (Fiori, 2020). Paulatinamente, os Estados Unidos da América do Norte (EUA) consolidaram seu poder imperial, promovendo inúmeras guerras e intervenções alémmar, sob diferentes governos, em nome de princípios "solidários" e "democráticos". Após o ataque de 11 de setembro de 200I, suas intervenções "humanitárias" e de “ajuda internacional” foram instrumentalizadas para fins geopolíticos (Almeida, 20 I I).

Uma sucessão de crises econômicas localizadas e inúmeros conflitos adentraram o século XXI, desembocando na grande crise financeira de 2008 que se espalhou pelo 
mundo desregulado e globalizado. As políticas de austeridade conduzidas a partir de então exacerbaram as restrições/imposições à formulação e implementação das políticas nacionais, estimularam a ascensão de governos de ultradireita, ${ }^{2}$ alguns explicitamente antidemocráticos e autoritários, e subverteram os preceitos fundacionais e procedurais do multilateralismo, exponenciando a sua crise. Vivenciamos desde então crescente piora das condições de vida de expressivo contingente populacional em todo o mundo: desemprego, informalidade do trabalho, crescente concentração de renda e riqueza, exacerbação do consumismo, exploração intensa e desordenada de recursos naturais, de espaços rurais e urbanos, poluição e proliferação de riscos catastróficos que ameaçam a sobrevivência no planeta.

Durante a segunda década do século XXI, os EUA, agora um poder imperial explícito e claramente unilateral, se desvincularam completamente de qualquer compromisso com a coesão do sistema interestatal e a promoção do desenvolvimento no mundo, desconsiderando, e tentando destruir, o sistema multilateral e qualquer ordem que não fosse em defesa de seus próprios interesses nacionais (Fiori, 2019). Como consequência, exacerbaram-se as disputas no sistema interestatal, com resistências cada vez mais frequentes (Obsal \& Tricontinental, 2020) e revides de outros Estados, que utilizam inclusive os mesmos mecanismos intervencionistas da política externa norte-americana. A disputa geopolítica explícita entre EUA e China é escancarada com a pandemia de Covid- 19.

\section{GOVERNANÇA GLOBAL E DO SETOR SAÚDE}

No concernente à governança do setor Saúde, termo que preferimos, constatamos nessa dinâmica a restruturação da governança global no mesmo período.

O termo governança incorpora questões relativas aos padrões de articulação e cooperação entre diferentes atores, a partir de arranjos institucionais e mecanismos, formais e informais, que os coordenam e regulam, segundo determinados princípios e diretrizes. O sistema internacional e suas agências é parte relevante desse processo formal de condução global, no qual os Estados nacionais ocupam posição de destaque, apesar das grandes assimetrias de poder entre eles, da dominância das grandes potências e das disputas por esse lugar. O conjunto de forças composto por distintos atores - públicos, privados, da sociedade civil, transnacionais - cada vez mais numerosos, mais ou menos institucionalizado e que extrapola o poder estatal ainda que

\footnotetext{
2 Ultradireita é entendida aqui como resultante da fusão do neoliberalismo econômico com o neoconservadorismo político, social e cultural, que expressa um feroz ataque à democracia, às políticas sociais de cunho solidário $e$ à diversidade.
} 
articulado com ele, cresceu muito a partir dos anos 1990 e constitui outra dimensão da governança. Essa pletora de atores configura uma intrincada teia de relações, um sistema cada vez mais denso de instituições públicas e privadas entrelaçadas, em escala nacional, internacional e transnacional.

As mudanças nas relações de poder decorrentes afetaram a articulação entre os processos de decisão em nível global e sua implementação regional, nacional ou local, e vice-versa. Aumentaram as coalizões intergovernamentais de grupos de países (os grupos G), em âmbito regional e geopolítico (p. ex., Mercosul, Ibas, Unasul, Brics, União Africana), além de outros atores não governamentais.

Essa dinâmica, associada aos valores neoliberais, conferiu predominância ao setor privado lucrativo, a doadores de programas verticais, organizações filantrópicas e organizações não governamentais (ONGs), interferindo nos processos de decisão em todos os níveis e, portanto, na governança global (Almeida, 202I). Esse panorama impulsiona a institucionalização de novos arranjos: parcerias público-privadas (PPPs) a partir de diferentes iniciativas globais, redes transgovernamentais e transnacionais que atuam junto com os órgãos multilaterais, ou paralelamente a estes, com proeminência crescente. E tem resultado em inflexões substantivas, não apenas no financiamento e organização dos cuidados de saúde prestados às populações, mas também na produção e distribuição de insumos essenciais para suprir as necessidades dos indivíduos e coletividades, em territórios e contextos específicos, ou seja, interfere significativamente na governança do setor Saúde.

Assim, governança refere-se a um processo dinâmico, cuja análise requer identificar a configuração de atores e levar em consideração as relações de poder (econômico e político-ideológico) entre eles e os valores éticos e morais presentes nas negociações em diferentes níveis políticos (nacional, global, regional), as quais são parcialmente determinadas pelo contexto e pela questão específica.

O reconhecimento de que saúde é uma questão multissetorial requer uma governança correspondente, pois está submetida a (e modelada por) regulamentações, tendências e desenvolvimentos estabelecidos em outras áreas de políticas. Portanto, a governança do setor Saúde deve ser entendida como um espaço político amplo, complexo e imanente aos processos contemporâneos de globalização, marcado por inflexões históricas, agudas divisões políticas, ideacionais e motivações conflitantes. Nesse espaço se constroem discursos sobre a saúde global que competem entre si e se materializam em políticas internacionais promovidas e defendidas por diferentes organizações, instituições, agências e coalizões, permeadas por interesses diversificados e poderosos (Almeida, 202I). 
Esse é o cenário em que a pandemia de Covid- 19 se espalha pelo mundo, exacerbando os resultados desastrosos das últimas décadas e descortinando as dificuldades inerentes a essas configurações.

\section{A ONU E A LIDERANÇA DA OMS NA SAÚDE}

A resposta multilateral das Organização das Nações Unidas (ONU) como um todo na pandemia de Covid-19 deixou a desejar, apesar dos esforços do secretário-geral, António Manuel de Oliveira Guterres (Quadro I).

Quadro I - Ações de organizações da ONU e outras intergovernamentais voltadas para a pandemia (exceto OMS)

\begin{tabular}{|c|c|}
\hline Organização & Ação / Crítica \\
\hline \multicolumn{2}{|r|}{ Âmbito global } \\
\hline $\begin{array}{l}\text { Secretário-geral, } \\
\text { António Guterres }\end{array}$ & $\begin{array}{l}\text { Grande protagonismo, em 4/02/2020 acionou a Política de Gestão de Crises } \\
\text { da ONU, o maior nível possível de alerta no sistema, pela primeira vez em } \\
\text { uma emergência em saúde }\end{array}$ \\
\hline $\begin{array}{l}\text { Conselho de } \\
\text { Segurança }\end{array}$ & $\begin{array}{l}\text { Apresentou certa paralisia diante da disputa entre EUA e China, não aprovou } \\
\text { declaração definindo a pandemia de Sars-Covid-2 como uma ameaça à } \\
\text { segurança e à paz mundial (como anteriormente com a HIV/Aids) } \\
\text { Debilitou a proposta de cessar-fogo planetário } \\
\text { Mantém manifestações tímidas e sem resultados práticos concretos }\end{array}$ \\
\hline $\begin{array}{l}\text { Respostas } \\
\text { conjuntas } \\
\text { dos órgãos } \\
\text { especializados }\end{array}$ & $\begin{array}{l}\text { Formulação do Plano Humanitário Global e dinamização do Fundo Central de } \\
\text { Resposta à Emergência da Coordenação de Assuntos Humanitários. } \\
\text { Organização das Nações Unidas para a Alimentação e a Agricultura (FAO), } \\
\text { Conselho Econômico e Social das Nações Unidas (Ecosoc) e Programa das } \\
\text { Nações Unidas para o Desenvolvimento (Pnud) também se manifestaram na } \\
\text { Assembleia Geral da ONU, ainda que de forma vaga e com recomendações } \\
\text { mais retóricas do que propositivas, reiterando a função da OMS na } \\
\text { governança da pandemia }\end{array}$ \\
\hline \multicolumn{2}{|r|}{ Âmbito regional } \\
\hline $\begin{array}{l}\text { Comissão } \\
\text { Econômica para a } \\
\text { América Latina e } \\
\text { o Caribe (Cepal) }\end{array}$ & $\begin{array}{l}\text { Acompanhamento da pandemia na região } \\
\text { Elaboração constante de documentos e estudos sobre os desdobramentos } \\
\text { do processo pandêmico e cenários para um futuro (próximo e possível) } \\
\text { pós-pandemia }\end{array}$ \\
\hline $\begin{array}{l}\text { Organização Pan- } \\
\text { Americana da } \\
\text { Saúde (Opas) }\end{array}$ & $\begin{array}{l}\text { Papel relevante de referência regional, tanto na retransmissão das estratégias } \\
\text { formuladas em Genebra quanto no acompanhamento da dinâmica regional da } \\
\text { pandemia }\end{array}$ \\
\hline
\end{tabular}


Quadro I - Ações de organizações da ONU e outras intergovernamentais voltadas para a pandemia (exceto OMS) (continuação)

\begin{tabular}{|c|c|}
\hline Organização & Ação / Crítica \\
\hline \multicolumn{2}{|r|}{ Âmbito global } \\
\hline \multirow{5}{*}{$\begin{array}{l}\text { Arranjos ou } \\
\text { coalizões } \\
\text { regionais do Sul } \\
\text { geopolítico }\end{array}$} & $\begin{array}{l}\text { O Mercado Comum do Sul (Mercosul) não conseguiu se organizar para } \\
\text { nenhuma ação conjunta }\end{array}$ \\
\hline & $\begin{array}{l}\text { A União de Nações Sul-Americanas (Unasul) havia sido desmontada, por } \\
\text { problemas político-ideológicos desencadeados pelo Brasil e outros governos } \\
\text { de extrema direita na região. Esses mesmos governantes criaram uma nova } \\
\text { organização, o Foro para el Progreso de America del Sur (Prosur), que não } \\
\text { decolou e desapareceu na pandemia. Como resultado, não foi desenvolvida } \\
\text { nenhuma coordenação ou cooperação efetiva de ações para enfrentamento da } \\
\text { pandemia na América do Sul }\end{array}$ \\
\hline & $\begin{array}{l}\text { Observa-se a exceção na América Central e Caribe, onde foi possível } \\
\text { enfrentar discordâncias e se conseguiu alguma cooperação sub-regional com } \\
\text { financiamento externo }\end{array}$ \\
\hline & $\begin{array}{l}\text { A coalizão Brics (Brasil, Rússia, Índia, China e África do Sul), que teria } \\
\text { potencial para uma atuação mais efetiva em prol dos países do Sul global, } \\
\text { não conseguiu atuar conjuntamente de forma efetiva }\end{array}$ \\
\hline & $\begin{array}{l}\text { A União Africana (UA) firmou parceria entre a African Union Comission, } \\
\text { o CDC Africa e a Coalition for Epidemic Preparedness Innovations (Cepi) e } \\
\text { criou o African Vaccine Acquisition Trust (Avat), para fortalecer a resposta } \\
\text { regional à Covid- 19, incluindo apoio aos sistemas de saúde e à produção de } \\
\text { vacinas para a região. Para tanto, realizaram a African Vaccine Manufacturing } \\
\text { Virtual Conference em meados de abril de } 202 \text { I. A UA continua lutando para } \\
\text { conseguir vacinas e lidando com inúmeros problemas da região }\end{array}$ \\
\hline \multicolumn{2}{|r|}{ Grandes financiadores } \\
\hline $\begin{array}{l}\text { Grupo Banco } \\
\text { Mundial }\end{array}$ & $\begin{array}{l}\text { O Banco Interamericano de Desenvolvimento (BID) e o BCIE destinaram } \\
\text { créditos emergenciais para a região das Américas do Sul e Central }\end{array}$ \\
\hline $\begin{array}{l}\text { Banco Centro- } \\
\text { Americano } \\
\text { de Integração } \\
\text { Econômica (BCIE) }\end{array}$ & $\begin{array}{l}\text { O grupo Banco Mundial e outros bancos regionais, como o BID, destinaram } \\
\text { bilhões de dólares para os programas de vacinação nos países de rendas } \\
\text { média e baixa, que podem ser utilizados tanto para compra de vacinas } \\
\text { quanto para a logística da vacinação }\end{array}$ \\
\hline $\begin{array}{l}\text { Afreximbanke } \\
\text { Africa Finance } \\
\text { Corporation }\end{array}$ & $\begin{array}{l}\text { Firmaram compromisso com a União Africana para apoiar a região no } \\
\text { enfrentamento da pandemia }\end{array}$ \\
\hline
\end{tabular}

Fonte: vários autores apud Almeida, 2021.

A OMS, por sua vez, tem se esforçado para cumprir seu papel a contento, apesar das inúmeras críticas ao multilateralismo, dos ataques de diferentes governos, da deslegitimação de seu papel, da perda de poder e dos revezes das últimas décadas 
no aprendizado de como lidar com pandemias potencialmente danosas (Almeida $\varepsilon$ Campos, 2020) (Figura I).

Figura I - Atuação criticada da OMS em algumas pandemias recentes - 1990 a 2004

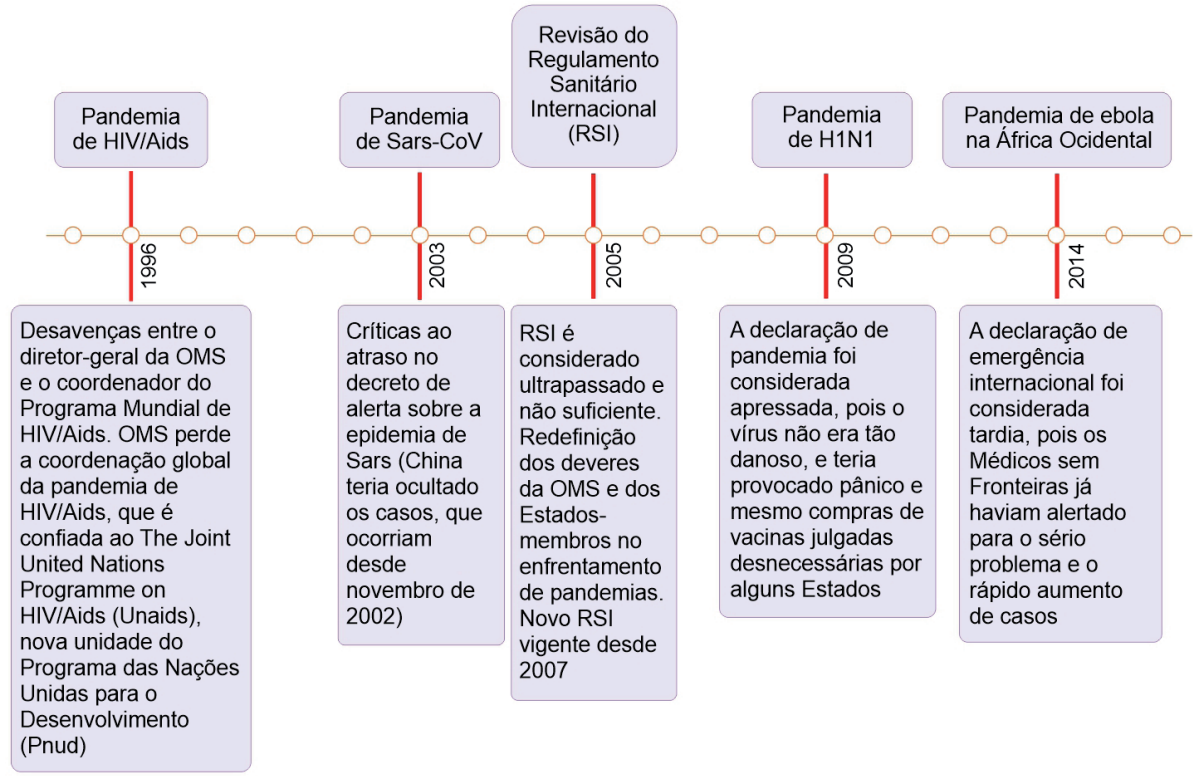

Fonte: elaboração própria com base em Almeida E Campos, 2020, Quadro I.

A liderança oficial da OMS configura-se como um espaço social e político de embates, negociações e enfrentamentos que refletem a dinâmica mais ampla do multilateralismo e da ordem mundial, assim como do setor Saúde como um todo (Almeida E Campos, 2020). Como qualquer organização multilateral, é uma "arena em que os atores orientam suas ações em relação a outros atores" (Almeida, 2021 : 28). Há muitos anos, portanto, os debates e ações da OMS refletem as contradições geopolíticas e de sua estruturação histórica (Lima E Albuquerque, 202I), sobretudo aquelas entre o Norte e o Sul globais.

Especificamente em relação à Covid-19, a direção-geral da OMS foi cautelosa, na tentativa de não repetir os erros anteriores; mesmo assim não conseguiu evitar as críticas, e as dificuldades na coordenação global do enfrentamento da pandemia se sucedem (Figura 2). 
Figura 2 - Atuação da OMS no início da pandemia de Covid-19 - dez. 2019 a fev. 2020

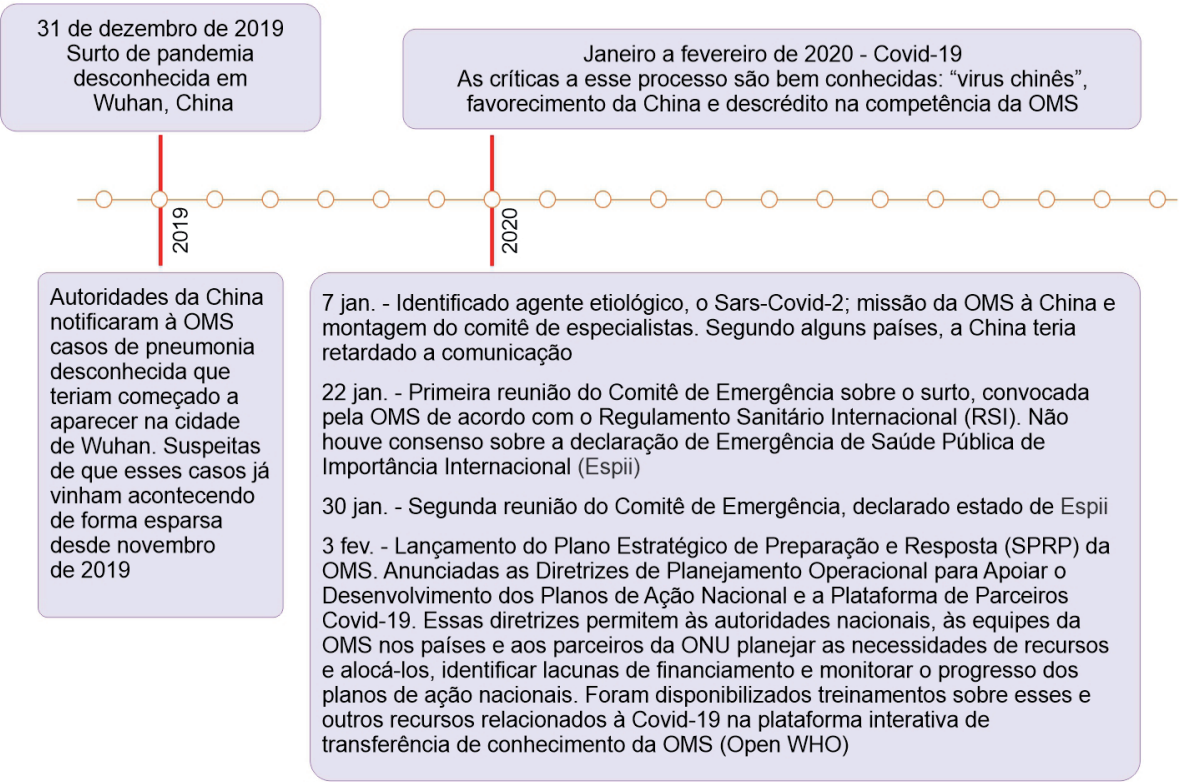

Fonte: elaboração própria com base em Almeida, 202 I, Quadro I.

A atitude dos EUA (na administração Trump) de desqualificar e marginalizar a OMS, assim como de boicotar acordos multilaterais ou regionais, coalizões ou instituições que representassem o multilateralismo ou nele se apoiassem, aprofundou a crise de legitimidade e de eficácia não apenas da OMS, mas de praticamente todas as organizações multilaterais da ONU (Almeida, 2021; Lima \& Albuquerque, 202 I). As críticas e reivindicações por "reforma" se repetem há décadas, muitas vezes encobrindo as tentativas de captura da organização por diversificados (e poderosos) atores interessados no setor (Almeida, 202I).

Os problemas que a OMS enfrenta são antigos e decorrem de escolhas que têm raízes internas e externas à organização, e as controvérsias são permanentes, especialmente visíveis na crise multidimensional desvelada pela Covid-19. Há décadas há consenso sobre a necessidade, diante dos "novos tempos", de mudanças, as quais, entretanto, não são fáceis nem se restringem à "pesada burocracia" ou à ausência de poder coercitivo, como argumentam alguns.

O crescente interesse na saúde como uma questão de política externa, de diplomacia e de governança, sobretudo a partir dos anos 2000, se traduziu em aumento de recursos financeiros para a denominada saúde global, mas não foi acompanhado de 
aprofundamento da reflexão sobre o real significado dessa relação. Paralelamente, a chamada diplomacia em saúde (ou diplomacia da saúde global) tem sido difundida de forma funcionalista, como argumentam alguns autores, "sem considerar as diferenças, e articulações, entre a formulação de uma política externa em nível nacional, a condução diplomática entre Estados e o funcionamento dos mecanismos de governança como instrumentos de uma ação coletiva coordenada" (Almeida, 2021 : 29).

Os descalabros que observamos no enfrentamento da Covid-19 evidenciam elementos cruciais e problemas conhecidos da governança setorial, agravados pela pandemia. Pelo menos duas dimensões dessa dinâmica contêm elementos de governança (ou denunciam a falta dela) e merecem ser analisadas: a extraordinária variação nas respostas nacionais e os enfrentamentos em relação ao desenvolvimento e aquisição de insumos, bem exemplificado pela questão das vacinas.

\section{As respostas nacionais à pandemia}

Apesar de os alertas da OMS e da progressão da pandemia terem ocorrido em um processo rápido, mas gradativo (da China para a Ásia, Europa, EUA, América do Sul e África), o que permitiria algum aprendizado entre os países, não foi isso que aconteceu. As respostas nacionais variaram muito em todas as regiões.

Em um primeiro momento, a prepotência ocidental se fez sentir nos diferentes países que subestimaram o perigo da nova pandemia, pois muitos não acreditavam que esta, vinda da Ásia, chegaria, por exemplo, à União Europeia (UE), quanto mais ao resto do planeta. Essa atitude de certo descaso se respaldou na experiência com as outras pandemias do século XXI ${ }^{3}$ (Roberts, 2020; Louis, 2020; Almeida \& Campos, 2020).

Essa certeza durou pouco, e o vírus alcançou os países europeus bastante desprevenidos. O mesmo não se pode dizer sobre os países continentais nas Américas, como Brasil e EUA, que, teoricamente, tiveram tempo de se preparar, mas a negação da pandemia e dos achados científicos, além do desdém pelas recomendações da OMS e o desrespeito à população por parte dos respectivos governantes, transformou o problema em uma enorme catástrofe humanitária, muito antes dessa caracterização se generalizar mundo afora.

\footnotetext{
${ }^{3}$ Entre tais experiência se incluem as duas epidemias de coronavírus (Sars-CoV), em 2002-2003, e a Middle East Respiratory Syndrome Coronavirus (Mers-CoV), em 20I2-20I3, ambas na Ásia com pouca difusão para outros países e rapidamente controladas; a do vírus HINI (2009), que não foi tão virulento e transmissível como inicialmente previsto; e a do vírus ebola na África, restrita a alguns países africanos (2014-2016, na Guiné, Libéria e Serra Leoa; e 2018, na República Democrática do Congo) (Almeida E Campos, 2020, quadro 4).
} 
Mesmo países com índices de preparação considerados bons para o enfrentamento de pandemias (como o Global Health Security Index) ${ }^{4}$ não tiveram bom desempenho, ao passo que outros, considerados não preparados, se saíram melhor, realçando a parcialidade deste e de outros índices globais e as vulnerabilidade dos sistemas de cuidados de saúde, mesmo nos países ricos (Lafortune, 2020; Baum, 2021; Cole E Dodds, 2021; Almeida, 2021).

A severidade da pandemia também tem mudado em um mesmo país ao longo do tempo, com picos subsequentes, produzidos pelo relaxamento das medidas preventivas (o trade-off saúde versus economia) ou pelas mutações do próprio patógeno. De qualquer forma, o mundo não se livrará completamente da Covid- I9, nem conseguirá controlá-la minimamente enquanto todos os países não puderem conter a disseminação do vírus em um nível considerado globalmente satisfatório. O mais provável é que a Covid- 19 se torne endêmica.

Resultados desses estudos apontam elementos relevantes na governança da pandemia em nível nacional que repercutiram na governança global do setor Saúde. Embora, historicamente, não sejam novos em situações pandêmicas, esses comportamentos adquiriram novos contornos na pandemia de Covid- 19 (Quadro 2).

Quadro 2 - Elementos relevantes nas respostas nacionais à pandemia

\begin{tabular}{|l|l|}
\hline \multicolumn{1}{|c|}{ Variável } & \multicolumn{1}{c|}{ Interferência no controle da pandemia } \\
\hline $\begin{array}{l}\text { Discordâncias } \\
\text { quanto a medidas de } \\
\text { prevenção e controle }\end{array}$ & $\begin{array}{l}\text { Foram intensas, sobretudo em relação a quando e como aplicar as medidas } \\
\text { de prevenção e contenção recomendadas, principalmente no tocante às } \\
\text { restriçães ao livre movimento dos cidadãos } \\
\text { Países que seguiram rigidamente as recomendaçães tiveram inicialmente } \\
\text { melhores resultados, que não se perpetuaram nos momentos seguintes } \\
\text { da pandemia, levando ao cansaço, à frustração e ao quase descrédito } \\
\text { da população, em muitos países, e até a movimentos de resistência } \\
\text { civil. Mesmo assim, muitos retomaram as medidas mais drásticas nos } \\
\text { momentos de recrudescimento do número de casos e de mortes, com } \\
\text { bons resultados }\end{array}$
\end{tabular}

${ }^{4}$ O GHS Index foi elaborado pelo Johns Hopkins Center for Health Security, a Nuclear Threat Initiative (NTI) e a Economist Intelligence Unit (EIU), para avaliar a capacidade de 195 países em relação à "segurança da saúde global” (Global Health Security Index, GHSI). Foi publicado pela primeira vez em 20I9, mas ganhou notoriedade em 2020 (GHSI, 2020). 
Quadro 2 - Elementos relevantes nas respostas nacionais à pandemia (continuação)

\begin{tabular}{|c|c|}
\hline Variável & Interferência no controle da pandemia \\
\hline Infodemia & $\begin{array}{l}\text { Teorias da conspiração, atitudes de negação da ciência e da própria } \\
\text { doença, difusão de tratamentos preventivos com medicamentos inefetivos, } \\
\text { fake news, relatos desencontrados, análises distorcidas etc. proliferaram } \\
\text { por toda parte (multiplicadas ad infinitum pelas redes sociais) } \\
\text { A tendência sensacionalista, em todo o mundo, das grandes mídias que, } \\
\text { além de não isentas ideológica e politicamente, privilegiam o "furo de } \\
\text { reportagem" e não a informação embasada e elucidativa sobre vários } \\
\text { problemas, confundiu e aterrorizou mais do que esclareceu }\end{array}$ \\
\hline $\begin{array}{l}\text { Tamanho da } \\
\text { população e } \\
\text { conexões internas } \\
\text { em um mesmo país }\end{array}$ & $\begin{array}{l}\text { Países mais ricos e com populações menores foram, em geral, mais ágeis } \\
\text { nas medidas de prevenção; os mais populosos tiveram mais dificuldades, } \\
\text { sobretudo se não foram tomadas as medidas de controle da disseminação } \\
\text { comunitária, nas grandes cidades e nas conexões internas do próprio } \\
\text { país, o que facilitou a rápida interiorização da pandemia, atingindo } \\
\text { inclusive áreas de difícil acesso e grupos vulneráveis que deveriam ser mais } \\
\text { protegidos (como as comunidades das periferias e indígenas) } \\
\text { O mesmo aconteceu regionalmente (em um mesmo país e entre países), } \\
\text { pois medidas de controle em um território delimitado não surtirão efeito } \\
\text { se os vizinhos não as implementarem também }\end{array}$ \\
\hline $\begin{array}{l}\text { Níveis de } \\
\text { desenvolvimento } \\
\text { econômico, graus } \\
\text { de desigualdade } \\
\text { e considerações } \\
\text { geopolíticas }\end{array}$ & $\begin{array}{l}\text { O desenvolvimento econômico teve menos impacto do que foi previsto; } \\
\text { porém, as imensas desigualdades entre países desenvolvidos ou em } \\
\text { desenvolvimento, e nas populações de um mesmo país (entre níveis de } \\
\text { renda, cor, raça e etnia) marcaram a diferença nos riscos e vulnerabilidades } \\
\text { no adoecimento e morte por Covid- } 9 \text { ou outras patologias } \\
\text { A desconsideração da crescente interconectividade mundial, da localização } \\
\text { geográfica e da organização regional, as disputas entre Estados e a } \\
\text { falta de padronização e regulação de políticas-chave de produção e } \\
\text { comercialização provocaram importante caos global, que resultou em } \\
\text { falta de insumos essenciais, corrupção e até aumento de ações criminosas } \\
\text { (desvios, pirataria, mercado paralelo, falsificações) }\end{array}$ \\
\hline $\begin{array}{l}\text { Diferenças na relação } \\
\text { com a sociedade }\end{array}$ & $\begin{array}{l}\text { A competência do Estado e de suas instituições, a transparência, a } \\
\text { confiança dos cidadãos nas suas lideranças, assim como na forma de } \\
\text { condução coordenada do enfrentamento da pandemia nacionalmente, } \\
\text { parecem ser elementos decisivos no trato com uma crise dessas } \\
\text { proporções. Em geral, países com sociedades mais uniformes, coesas e } \\
\text { atuantes, e com instituições estáveis e competentes tiveram melhores } \\
\text { resultados } \\
\text { Por sua vez, a capacidade das organizações da sociedade civil de atuar nas } \\
\text { comunidades de forma independente ou complementar às ações estatais, } \\
\text { a solidariedade e a empatia no contexto do desastre humanitário têm feito } \\
\text { toda a diferença }\end{array}$ \\
\hline
\end{tabular}


Quadro 2 - Elementos relevantes nas respostas nacionais à pandemia (continuação)

\begin{tabular}{|c|c|}
\hline Variável & Interferência no controle da pandemia \\
\hline $\begin{array}{l}\text { Fatores sistêmicos } \\
\text { isolados }\end{array}$ & $\begin{array}{l}\text { Características do sistema societário e do regime político, entre outros, } \\
\text { não podem ser responsabilizados, isoladamente, pelas diferenças } \\
\text { observadas nas respostas a essa crise multidimensional; no entanto, as } \\
\text { escolhas dos governantes e as circunstâncias políticas cotidianas parecem } \\
\text { muito importantes na modelagem das respostas de cada país }\end{array}$ \\
\hline $\begin{array}{l}\text { Capacidade de } \\
\text { resposta dos } \\
\text { sistemas de serviços } \\
\text { de saúde }\end{array}$ & $\begin{array}{l}\text { Em termos gerais, os sistemas de serviços de saúde financiados } \\
\text { majoritariamente com recursos públicos puderam oferecer melhores } \\
\text { condições de acesso e utilização pela população do que aqueles privados, } \\
\text { mistos ou bastante fragmentados } \\
\text { Contenção da transmissão comunitária, rastreamento e testes em massa } \\
\text { foram ações comprovadamente acertadas, assim como as medidas de } \\
\text { higiene, o uso de máscaras e o distanciamento físico } \\
\text { Entretanto, sistemas públicos cronicamente subfinanciados não tiveram } \\
\text { condições de atender às necessidades de suas populações; em vários } \\
\text { países, os cortes de recursos na área social, implementados pelas } \\
\text { políticas de austeridade, complicaram muito a situação e foram sérios } \\
\text { impedimentos para um desempenho mais efetivo. Além disso, todos os } \\
\text { problemas anteriores se refletem nos serviços de saúde, e muitos países } \\
\text { sofreram colapsos da atenção médica nos períodos mais críticos da } \\
\text { pandemia }\end{array}$ \\
\hline
\end{tabular}

Fonte: elaboração própria com base em vários autores (apud Almeida, 2021).

Ficou evidente, em muitos países, a enorme fragmentação dos sistemas de proteção social e de saúde, além do despreparo generalizado para o enfrentamento da pandemia, tanto pelas décadas de subfinanciamento e desmonte de todo o setor social com as políticas de ajuste e austeridade quanto pelas "reformas pós-welfare" implementadas em praticamente todos os países (Almeida, 2012, 2014; Casalí, Goldschmit \& Cetrángolo, 2021; Sojo, 2020; Godlee, 2021).

\section{As iniciativas da OMS e de países}

Para tentar minimizar as desigualdades entre os países no acesso aos insumos necessários para o controle da epidemia, a OMS implementou iniciativas específicas e mecanismos de financiamento e distribuição de insumos para os países de renda médiabaixa e baixa, apoiada por vários países e doadores (públicos e privados) (Almeida, 202 I, quadro I):

I. Fundo para arrecadar recursos financeiros, The Covid- I 9 Solidarity Response Fund for WHO, fruto de parceria entre a UN Foundation (com sede nos EUA) e a Swiss 
Philanthropy Foundation, SPF (com sede em Genebra). Os recursos arrecadados são encaminhados para a Covid-I 9 Strategic Preparedness e o Response Plan, para apoio aos países mais vulneráveis.

2. Access to Covid-19 Tools Accelerator (ACT-A ou Accelerator), mecanismo de financiamento que reúne países, doadores diversos, parceiros da indústria e da sociedade civil e várias PPPs, voltado para acelerar os desenvolvimentos, o aumento da produção e a distribuição equitativa de novos insumos necessários ao enfrentamento da Covid-19. Está apoiado em três pilares: métodos e reativos para diagnóstico, implementado pela Foundation for Innovative New Diagnostic (FIND) e pelo Global Forum; insumos terapêuticos, conduzido pela Unitaid e o Wellcome Trust; e o Covax Facility, o pilar das vacinas, liderado pela Gavi e a Cepi, ${ }^{5}$ junto com a OMS, apoiada pelo Fundo das Nações Unidas para a Infância (Unicef), para processos de aquisição de doses, frete, logística e armazenamento. Com a compra antecipada de vacinas pelos países ricos - com o Advanced Market Commitment (AMC) e doação para os países menos aquinhoados (para vacinar $20 \%$ de suas populações) -, o Covax pretendia promover a solidariedade e garantir vacinação de, pelo menos, 20\% da população mundial até 2021 .

3. Covid- 19 Technologic Access Pool (C-TAP), criado a partir da proposta da Costa Rica e da Solidarity Call for Action. Consiste em um pool de conhecimentos tecnológicos (open science), voluntariamente disponibilizado e aberto, arbitrado pelas vias multilaterais. Coordenado pela própria OMS juntamente com outras agências da ONU, aproveita mecanismos já existentes na organização, conectando diferentes plataformas. Não decolou e teve como principais opositores EUA, Reino Unido e Suíça.

Mais recentemente, as discussões (e acordos restritos) vêm acontecendo também em relação aos novos medicamentos para tratamento da Covid-19, que parecem efetivos na redução da gravidade da doença e do número de hospitalizações, mas são

\footnotetext{
${ }^{5}$ Gavi, Global Alliance for Vaccines, também uma PPP, foi criada em 2000 com a ajuda de vários parceiros - governos de países, a própria OMS, o Banco Mundial, a FBMG e outros doadores (ONGs, associações profissionais e comunitárias, organizações religiosas, universidades, fabricantes de vacina, institutos de pesquisa, entre outros) - para promover a distribuição de vacinas nos países em desenvolvimento. O IFFIm, International Finance Facility for Immunisation, instituição filantrópica inglesa fundada em 2006, angaria fundos para a PPP. E a Cepi, Coalition for Epidemic Preparedness Innovations, é uma PPP concebida em 2015 pelo governo da Noruega, à qual se juntaram outros países (Alemanha, Japão, União Europeia e Reino Unido, configurando um "consórcio de nações") e fundações filantrópicas (FBMG e Wellcome Trust). Foi formalizada em 2017, no Fórum Econômico Mundial de Davos, e trabalha junto da OMS. Dedica-se ao desenvolvimento de vacinas para o controle de epidemias ou pandemias.
} 
muito caros e sua produção está restrita a poucas farmacêuticas privadas. Um bom exemplo é o molnupiravir, um antiviral oral produzido pela Merck Sharp \& Dohme, que assinou acordo de licenciamento voluntário com o Medicine Patent Pool, possibilitando sublicenciamentos para outros 105 países de baixa renda. O problema é que nesse tipo de licença o detentor da patente é quem define quais países podem ser beneficiados (em qual região do mundo) e, portanto, exclui os países de renda média-alta e com capacidade produtiva (Bermudez \& Bermudez, $202 \mathrm{l} \mathrm{b).}$

Além dessas iniciativas, em outubro de 2020 a Índia e a África do Sul propuseram à Organização Mundial do Comércio (OMC) o Trips Waiver, fortemente apoiado pela OMS e por mais de cem países em desenvolvimento. Solicitaram aos membros da OMC a isenção temporária de quatro categorias de direitos de propriedade intelectual - copyright, desenho industrial, patentes e informações confidenciais (segredos comerciais) que estejam sob o Acordo Trips (Agreement of Trade-Related Intellectual Property Rights) para a produção de todos insumos (medicamentos, testes, vacinas) relacionados à Covid-19, até que a pandemia estivesse controlada e a maioria da população mundial estivesse segura. As farmacêuticas transnacionais e países ricos (Reino Unido, EUA, Canadá, Noruega, UE e Japão, entre outros) se opuseram veementemente. Com o governo Biden os EUA passaram a apoiar o waiver, declaração de peso e impacto político mundial, mas sem consequências práticas imediatas. Até o final de outubro de 2021 a questão continuava em discussão/negociação na OMC, com propostas alternativas e revisões, sem solução para o impasse, apesar das várias reuniões do Conselho do Trips. A $12^{\text {a }}$ Conferência Ministerial da OMC, prevista para novembro-dezembro de $202 \mathrm{I}$, não foi realizada.

Os debates têm sido acirrados e adquiriram contornos dramáticos com a insuficiência de vacinas, principalmente para os países não produtores e mais pobres. Diante da necessidade urgente de aumentar a sua produção em nível mundial/regional e do impasse na OMC, desde julho de 2021 a OMS vem implementando um novo mecanismo, o New Technology Transfer Hub (WHO, $202 \mathrm{I}$ a), para expandir a capacidade de produção e melhorar o processo de acesso às tecnologias nos países de renda baixa e média, priorizando inicialmente um tipo de vacina produzida com tecnologia de RNA mensageiro (mRNA), como a da Pfizer e a da Moderna. O primeiro hub começou a ser implantado na África do Sul e foi lançada convocatória internacional para outras regiões (MPP, 202 I). Em setembro de 202 I o Instituto de Tecnologia em Imunobiológicos (Bio-Manguinhos), da Fiocruz, foi selecionado como o centro para desenvolvimento e produção de vacinas na América Latina (Lang, 202 I).

O Accelerator divulgou no final de outubro de 2021 um novo plano estratégico para os próximos 12 meses (WHO, $202 \mathrm{lb}$ ), a partir de recomendações de uma revisão 
independente, publicada no início do mês (WHO E Dalberg, 202I). Redefiniu suas metas e os recursos necessários para cumpri-las (US 23,4 bilhões) (Tabela I). E, no final desse mesmo mês, em mais uma Cúpula do G20, o diretor-geral da OMS apelou aos países-membros que apoiem os esforços para o controle da pandemia (Alcazar $\&$ Buss, 202I). E a Cepi renovou seu Conselho, introduzindo novos membros. ${ }^{6}$

O C-TAP, por sua vez, não teve nenhuma tecnologia cedida, apesar de haver interesse de fabricantes de vacinas e outros insumos. E, em setembro de 2021, foi criado pela OMS o Grupo Técnico Consultivo (Technical Advisory Group, TAG) para tentar apoiar o seu desenvolvimento. ${ }^{7}$

\section{OS IMPASSES}

Várias dificuldades e impasses têm comprometido a efetividade desses mecanismos. A falta de acesso a insumos estratégicos, um drama para os países mais pobres, seja para a proteção individual, para testes diagnósticos ou cuidado hospitalar dos doentes, seja para medicamentos e vacinas (cruciais para salvar vidas, conter a disseminação e evitar o colapso dos serviços hospitalares), desnudou a feroz competição entre Estados nacionais, a falta de solidariedade, o peso mundial do setor privado e das disputas geopolíticas nesse processo.

O "nacionalismo das vacinas" (ou o "apartheid vacinal") exemplifica magistralmente essa situação global. Diante do desafio de vacinar cerca de 70\% da população mundial (em torno de I I bilhões de pessoas), assistimos a compras bilaterais antecipadas (entre país e empresas produtoras), por países ricos ou blocos de países desenvolvidos (onde habita cerca de um terço da população mundial), de quantidades de duas a quatro vezes maiores do que as necessárias, deixando desabastecido o restante do mundo. A falta de transparência desses contratos e a recusa a maior flexibilização dos direitos patentários é demonstração clara da "desordem" e do poder (sem limites) do setor privado neste mundo ultraliberal. As várias rodadas de negociações na OMC confirmam as dificuldades de aprovação de um acordo consensual. Alguns países reviram suas

\footnotetext{
${ }^{6}$ A presidente da Fiocruz, Nísia Trindade Lima, foi convidada como membro do Conselho da Cepi, que supervisiona o desempenho e a prestação de contas da PPP. O Conselho é composto por 12 membros, com direito a voto, e pretende garantir que a organização contribua para melhorar a preparação contra epidemias e pandemias no mundo. Nísia será membro de uma das quatro comissões desse conselho, a de Auditoria e Risco (Azevedo, 202I).

${ }^{7}$ Esse novo grupo técnico, composto por dez membros e com mandato de dois anos renováveis, tem entre seus integrantes Jorge Bermudez, pesquisador da Ensp/Fiocruz (Covid- 19: pesquisador..., 2021).
} 
posições, exceto a UE, que continua irredutível na oposição ao waiver, aceitando, no máximo, as "licenças compulsórias". 8

Esse debate ampliou a visibilidade da importância das transferências tecnológicas ${ }^{9}$ para aumentar rapidamente a produção de vacinas e atender à demanda global, algo difícil de se conseguir apenas com alguns poucos produtores. É um processo habitual entre as empresas privadas, assim como as intervenções governamentais para estimular essas "cooperações", que fortalece ainda mais a posição das grandes farmacêuticas, sobretudo em um cenário de emergência internacional e necessidade urgente de insumos (como as vacinas) em grande quantidade. O presidente Biden, dos EUA, utilizou o Defense Production Act para facilitar esse partilhamento entre empresas privadas norteamericanas e incrementar a produção de vacinas para abastecimento nacional. E, mais recentemente, tem se comprometido com a produção norte-americana de vacinas para doação aos países de baixa renda.

Reuniões de agências internacionais, ministros (de Economia, Finanças, Saúde, Comércio) e cúpulas de grupos de países (G7, G20), oficiais ou paralelas, assim como as assembleias da ONU e de suas agências, têm se sucedido com reiteração de práticas/ recomendações e nenhum avanço substantivo em direção à superação do impasse global (Alcazar E Buss, 202I).

Não há como aprofundar aqui esses temas, aliás muito debatidos por vários autores em artigos, lives e webinários, mas registramos alguns comentários.

Em primeiro lugar, parece-nos importante prestar atenção nos mecanismos que estão sendo implementados na OMS, como o C-TAP e o Accelerator. Em princípio, poderiam ser complementares, mas na realidade se contrapõem, pois traduzem diferentes opções políticas e evidenciam conflitos subjacentes: distintas formas de tentar resolver

\footnotetext{
${ }^{8}$ Licença compulsória não é o mesmo que waiver. Este é um dispositivo aplicável país a país e produto a produto, e depende da vontade/condição política e técnica do país. Um dos fatores a serem considerados nesses casos é a constante evolução geral do cenário patentário, o que impõe dificuldades extras na continuidade da produção (Chamas, 202I).

${ }^{9}$ Transferência tecnológica é o processo de repasse de conhecimento técnico, know-how, tecnologias complexas, de uma empresa/instituição para outra (p. ex., no Brasil, AstraZeneca e Fiocruz; Sinovac e Butantan). Consiste em acordos bilaterais arbitrados por contratos, que possuem cláusulas de confidencialidade. Pressupõe aprendizado e adaptações trabalhosas, com prazo de implementação de, usualmente, entre 5 e 7 meses, podendo ser bem maior. É uma forma de proteção dos direitos de propriedade intelectual do detentor e de seus ativos (financeiros e comerciais). Inclui também a produção dos insumos farmacêutico (IFAs) necessários à fabricação do produto objeto da transferência, que não raro requer outras negociações e está sujeita a restrições no mesmo contrato.
} 
problemas que envolvem bens públicos globais que, na realidade, são tratados como bens privados. Essa disputa não é nova, mas se exacerbou nesta pandemia.

Em segundo lugar, note-se que a maioria das principais vacinas disponíveis está sendo produzida em grandes empresas transnacionais localizadas no Norte geopolítico, coligadas com outras menores ou com universidades, ou com "parceiros" habituais no Sul (p. ex., Índia e Brasil), apoiados por processos de transferência tecnológica. Além disso, o desenvolvimento e produção em alta velocidade de produtos essenciais, como estamos observando, é especialmente beneficiado pela cumulatividade de conhecimentos e aprendizados específicos, que conferem vantagem comparativa àquelas empresas que trabalham com colaborações e apoio público em todas as etapas do processo de desenvolvimento de novos produtos (Chamas, 2020).

Considerando essas duas premissas e estudos de vários autores, constatamos que:

1. As pesquisas básicas que possibilitaram o desenvolvimento das vacinas para a Covid- 19 vêm sendo financiadas com recursos públicos (investimento de governos em universidades e institutos) há décadas; a colaboração global no compartilhamento de dados de sequenciamento genômico e de informações de saúde pública também foram essenciais, e não começaram agora. Ademais, os produtores privados de vacinas receberam recursos públicos adicionais para o processo de desenvolvimento e produção da nova vacina (p. ex., dos EUA e da UE). Mesmo assim, os países financiadores cederam o monopólio das patentes para as empresas privadas. Os EUA são pioneiros nessa prática desde os anos 1980, quando foi aprovado o Bayh-Doyle Act, ${ }^{10}$ que embora seja uma legislação nacional, tem enorme impacto no âmbito global, como estamos presenciando.

2. É bem conhecido que o sistema de inovação e pesquisa de produtos biomédicos e farmacêuticos é predominantemente orientado pelo mercado. Pesquisa $E$ Desenvolvimento (PED) de vacinas para pandemias/epidemias envolve ampla gama de atores e relativamente limitada prospecção de geração de renda; não por acaso várias doenças, como a HIV/Aids e malária, por exemplo, ainda não têm vacina, mas seu tratamento pode ser beneficiado por esses novos desenvolvimentos.

\footnotetext{
10 O Bayh-Doyle Act foi aprovado nos EUA em 1980 pelos dois partidos, Democrata e Republicano, e leva os nomes de dois ilustres congressistas, um de cada partido. O principal objetivo dessa lei foi permitir que empresas privadas obtivessem monopólio de patentes para a fabricação de produtos desenvolvidos com base em pesquisas financiadas com recursos públicos, sem qualquer contrapartida - controle de preços ou outro tipo de regulação. O principal resultado negativo foi o aumento exponencial dos preços dos medicamentos desde então (Baker, 202I).
} 
3. A Cepi e a Gavi, como PPPs, foram engendradas para enfrentar um antigo paradoxo do desenvolvimento de vacinas: é um bem essencial/crucial, mas seu desenvolvimento e sua distribuição são historicamente subvalorizados, devido tanto a questões de mercado quanto a certas particularidades biotecnológicas das próprias vacinas. Esse panorama mudou completamente com a Covid-19, no que se refere tanto ao mercado (previsão de bilhões de doses, provavelmente por bom tempo) quanto à acumulação tecnológica.

4. O Covax Facility teve que rever suas normas e fazer concessões a países abastados, para tentar assegurar os recursos financeiros ainda muito insuficientes (Usher, 202 I); e a Gavi continua tentando convencer os países a contribuírem, seja com recursos financeiros, seja com doações de doses de vacinas (Tabela I).

5. Vários autores e comentaristas têm mostrado os problemas desse mecanismo (Usher, 202I; Bermudez E Bermudez, 202 la), que não altera as questões estruturais subjacentes. A crença de que esse tipo de solidariedade forjada funcionaria no mundo do século XXI não se sustenta diante da realidade. A solução proposta, então, é assistencialista/beneficente: doação pelos países do centro de doses excedentes, como apregoa o G7," ou produzidas especialmente para serem doadas; ou de empresas privadas (p. ex., a Mastercard Foundation) (Adepoju, 2021). Mantém-se, assim, a submissão e dependência dos países mais pobres àqueles que têm dinheiro.

6. O modelo inovador das PPPs é atraente e materializa uma tendência que vem dos anos 1990: a institucionalização de parcerias transversais como solução para problemas estruturais da inovação em PED (assim como na provisão de serviços), com papel crucial na superação dos "incentivos imperfeitos da pesquisa biofarmacêutica", assim como para fazer frente a deficiências na arquitetura da governança global do setor Saúde. As PPPs foram pensadas como um novo lócus para funções de financiamento, coordenação e regulação que, historicamente, foram desempenhadas pelo Estado, pelo mercado ou ambos, articulados e regulados. Nessa perspectiva de "regulação de inovações" o mercado é considerado como o paradigma primordial para se alcançar "benefícios sociais" (bens públicos?) e tem sido um aspecto-chave nas visões da globalização nas últimas três décadas.

\footnotetext{
" Note-se que os sete países que compõem o G7 detêm " $60 \%$ da riqueza e 35\% do PIB mundial, com cerca de $10 \%$ da população global, sendo, porém, responsáveis por $50 \%$ das doses de vacina contra Covid- 19 contratadas até o momento [outubro de 202 I]" (Bermudez \& Bermudez, 202 Ia).
} 
7. Os ganhos financeiros no mercado de ações das empresas privadas produtoras foram (e continuam a ser) astronômicos, desde o primeiro anúncio de um possível grau elevado de eficácia das vacinas, permitindo a ampliação e adaptação subsidiada de suas plantas produtivas (AstraZeneca, BioNTech) e o apoio de outras empresas menores (p. ex., Pfizer/BioNTech e a francesa Sanofi, e, nos EUA, Merck e Johnson E Johnson).

8. O argumento em favor da manutenção do monopólio das detentoras dos direitos de propriedade intelectual é o de que não adiantaria "quebrar patentes", pois isto atrasaria a produção, uma vez que não se trata de aplicar uma receita e que poucos laboratórios na periferia disporiam de capacidade tecnológica para produzir, dada a complexidade dessas vacinas e de outros insumos. Essa postura desqualifica evidências em contrário e desconsidera a urgência global na busca de soluções (Bermudez \& Bermudez, 202 la).

9. A produção de vacinas, e de matéria-prima para tal, não é operação trivial, requer altos investimentos (públicos e privados) de longo prazo, capacidade instalada, recursos humanos treinados, agências reguladoras efetivas etc. A experiência de alguns países considerados em desenvolvimento atesta que é possível a produção fora do "centro", desde que haja vontade política e políticas públicas (nacionais e internacionais) que reconheçam o imperativo de superar a dependência tecnológica de poucos produtores (países e farmacêuticas transnacionais) e possibilitem o fortalecimento da capacidade produtiva e regulatória em diferentes regiões.

Em síntese, a exclusividade de direitos de propriedade intelectual fortalece a acumulação de capacidade inovadora pelas farmacêuticas privadas, é fundamental na concorrência e visa a alcançar lucros extraordinários (Chamas, 2020).

Alguns dados reforçam nossos argumentos. A concentração de insumos e da vacinação no mundo abastado é impactante (Tabela I). 
Tabela I - Iniquidades na vacinação mundial

Total de doses de vacinas administradas e de
testes utilizados na população mundial

Vacinas asseguradas

Canadá, Austrália, Nova Zelândia, Reino Unido, EUA (jan. 2021)

Covax (nov. 2021)

- Total previsto

- Asseguradas

- Recebidas por doação

- Compra potencial (meta)

Doação dos países do G7 para o Covax (9 nov. 2021)*

- Total anunciado

- Entregues

\begin{tabular}{l|c}
\multicolumn{1}{c|}{ Previsão de desperdício de doses acumuladas } & $\mathrm{N}$ \\
\hline $\begin{array}{l}\text { Até o final de } 2022 \text { (expiração da validade, caso não sejam utilizadas), } \\
\text { em posse de dez países, em grande maioria de alta renda }\end{array}$ & 3,8 bilhões \\
\hline \multicolumn{1}{c}{ Novas metas do Accelerator, plano estratégico até set. 2022} & $\mathrm{Ne} \%$ \\
\hline $\begin{array}{l}\text { Total recursos financeiros necessários } \\
\text { Covax }\end{array}$ & US $\$ 23,4$ bilhões \\
- Cobertura vacinal países do Advanced Market Commitment, AMC \\
(91\% de baixa renda). \\
- Taxa mínima de testagem em I44 países de baixa e média rendas \\
- Garantia de acesso aos tratamentos existentes, incluindo oxigênio, \\
nos países de renda média e baixa
\end{tabular}

Fonte: elaboração própria com base em Pai, 202 I; Our World in Data, 202 I e WHO, 202 la, 202 lb.

* Os 7 países anunciaram doação de doses de vacina e entregaram parte do anunciado, em quantidades variáveis. Os EUA foram o maior doador até 09/1 I/2021.

$\mathrm{Ne} \%$

7,34 bilhões

$4,2 \%$

$51,2 \%$

200-400\% da população

5.274 .400 bilhões (100\%)

2.534 .000 bilhões (25\%)

730.400 milhões (7\%)

2.010 bilhões (68\%)

Pouco mais de $10 \%$ do anunciado

1.611,35 bilhões

198,60 milhões

$\mathrm{N}$ (n) 
No final de fevereiro de 2021, as primeiras doses de vacinas começaram a chegar aos países em desenvolvimento a partir do Covax. A distribuição prosseguiu lentamente desde então, com grande difusão nas mídias, mas sempre lidando com a escassez e a dificuldade, muito menos divulgadas, de assegurar as entregas. Soma-se a isso a polêmica suscitada pelo "passaporte da vacina" e seus desdobramentos.

Por fim, a necessidade de uma terceira dose para grupos populacionais mais sujeitos a adoecer, mesmo depois de vacinados (idosos $>70$ anos e imunodeprimidos), ou possível reforço a todos já vacinados para fazer frente às mutações do vírus (p. ex., variante delta, inversamente correlacionada com a taxa de vacinação), e a vacinação de crianças e adolescentes recolocam o dilema da insuficiente produção mundial. Da mesma forma, as doações evidenciam o problema da validade das doses adquiridas: países pobres, sobretudo na África, têm referido dificuldades logísticas para usar as vacinas doadas com data próxima de expiração, arriscando ter que as destruir, além da falta de seringas adequadas à aplicação (Furneaux, Goldhill \& Davies, 202I).

\section{PARA CONCLUIR}

O panorama global de "desordem" ou de transição para uma nova ordem mundial e nacionalismos populistas de ultradireita nos confronta com um contexto complexo que nos atinge, como país da periferia capitalista, de forma deletéria e em várias dimensões. Não se trata de desconsiderar, ou minimizar, a conjuntura nacional, como já afirmamos, mas de ampliar o olhar, o que talvez nos ajude a entender melhor os enormes desafios que estamos enfrentando em escala global e se refletem em nossa região e em nosso país.

Não se desaprova a priori o enorme conjunto de iniciativas que envolvem amplo elenco de atores - públicos, privados, não governamentais -, primeiro porque já se consolidaram mecanismos relevantes nessas parcerias e, segundo, porque todos esforços são bem-vindos diante da catástrofe humanitária da Covid-19, além de outras pandemias que possivelmente virão. Porém, não é mais aceitável delegar atribuições eminentemente públicas a articulações que não enfrentam as bases das desigualdades globais. Existem mecanismos alternativos para apoiar inovações nas empresas privadas que não sejam a concessão de monopólio de direitos de propriedade. E mesmo que o monopólio seja legítimo, também pode ser administrado de diferentes formas, assim como o mercado pode ser estruturado e regulado de distintas maneiras. São escolhas políticas que definem esses parâmetros

Em certa medida, os desmandos locais se respaldam em vários outros atores, e a estes se aliam, nessa perversa dinâmica, submetida e reverente ao "sr. Mercado", a um setor privado que, em geral, trabalha para o aumento exponencial de seus lucros, to- 
talmente indiferente a qualquer solidariedade com os seres vivos, mesmo os humanos, considerados consumidores descartáveis quando não têm dinheiro. Além de entrópica e autodestrutiva, essa dinâmica atesta a falta de qualquer preocupação com o mundo ou as condições de vida na Terra.

Degradar nosso país até a posição de pária no sistema mundial, depois de ter alcançado, em passado recente, lugar de algum poder moral e de respeito internacional por ter sido protagonista em várias questões cruciais referidas à saúde que agora voltaram à agenda, com cores mais fortes, só é compreensível em uma perspectiva de destruição sem limites de certos governantes.

Os impasses estão em curso, as encruzilhadas são muitas e de difícil travessia. Não vislumbramos, por enquanto, nenhum vaga-lume no fim do túnel e tampouco sabemos se teremos algum "vencedor" nessas disputas, ou mesmo para onde vai caminhar este mundo em transição. Porém, a pandemia confirmou que enquanto não se conseguir enfrentar os problemas estruturais que mantêm e agudizam as enormes iniquidades globais, magnanimamente distribuídas em todos as dimensões e espaços territoriais, continuaremos semeando pestes e contando mortos.

Faz-se urgente, portanto, aprofundar as discussões sobre esses impasses e mudar os termos do debate para fortalecer o interesse público nos enfrentamentos inevitáveis

\section{REFERÊNCIAS}

ADEPOJU, P. Mastercard Foundation donates US $\$ 1.3$ billion to vaccinate 50 million Africans against Covid-19, 9 jun. 202I. Disponível em: <https://healthpolicy-watch.news/mastercard-foundationdonates-I-3b-to-boost-africas-fight-against-covid-19>. Acesso em: 10 jun. 2021.

ALCAZAR, S. E BUSS, P.M. Saúde global na Cúpula do G20 em Roma. Le Monde Diplomatique, São Paulo, I nov. 2021. Disponível em: <https://diplomatique.org.br/saude-global-na-cupula-do-g20em-roma/>. Acesso em: 2 nov. 2021 .

ALMEIDA, C. The treat from health securization: international perspectives on the public health implications of 9/I I, 20 I I. Australian and New Zealand Journal of Public Health, 35(4): 3 I 2, 20 I I.

ALMEIDA, C. Reforma de sistemas de saúde: tendências internacionais, modelos e resultados. In: GIOVANELLA, L. et al. (org.). Políticas e Sistemas de Saúde no Brasil. 2. ed. rev. ampl. Rio de Janeiro: Editora Fiocruz, 2012.

ALMEIDA C. O Banco Mundial e as reformas contemporâneas do setor Saúde. In: PEREIRA, JMM. A. E PRONK, M. (Orgs.). A Demolição de Direitos: um exame das políticas do Banco Mundial para a educação e a saúde (1980-20/3). Rio de Janeiro: Escola Politécnica de Saúde Joaquim Venâncio, 20 I 4. Disponível em: <http://www.epsjv.fiocruz.br/index.php?Area $=$ MaterialETipo $=8 \mathcal{E}$ Num $=240>$. Acesso em: 02 out. 2021. 
ALMEIDA, C. Governança do setor Saúde em um contexto mundial mutante e incerto - Brasil Saúde Amanhã. Rio de Janeiro: Fiocruz, 202I. (Texto para Discussão, 60) Disponível em: <https:// saudeamanha.fiocruz.br/wp-content/uploads/202 I/05/ALMEIDA-C-202 I-Governan\%C3\%A7aSetor-Saude-em-Contexto-Mundial-Mutante-Incerto-Fiocruz-Saude-Amanha-TD060.pdf>. Acesso em: 4 maio 2021.

ALMEIDA, C. \& CAMPOS, R. P. Multilateralismo, ordem mundial e Covid- 19: questões atuais e desafios futuros para a OMS. Saúde em Debate, 44 (n. esp. 4): 13-39, 2020.

AZEVEDO, C. Presidente da Fiocruz vai integrar organização que financia projetos de vacinas. Agência Fiocruz de Notícias, Rio de Janeiro, 16 set. 2021 . Disponível em: < https://agencia.fiocruz.br/presidenteda-fiocruz-vai-integrar-organizacao-que-financia-projetos-de-vacinas >. Acesso em: 16 set. 2021 .

BAKER, D. Beating Inequality \& Covid- I 9: tackle patent and copyright monopolies. News Click, 31 jan. 2021. Disponível em: <www.newsclick.in/dean-baker-beating-inequality-covid-19-tackle-patentand-copyright-monopolies>. Acesso em: 12 mar. 2021.

BAUM, F. et al. Explaining covid- 19 performance: what factors might predict national responses? British Medical Journal, 372(91): I-4, 2021. Disponível em: <www.bmj.com/content/372/bmj.n91 > Acesso em: 10 fev. 2021.

BERMUDEZ, L. \& BERMUDEZ, J. Covid- I 9: o mundo em um "apartheid de vacinas". CEE/Fiocruz, I 0 ago. 202 Ia. Disponível em: < https://naf.ensp.fiocruz.br/pt-br/covid-19-o-mundo-em-um-apartheid-devacinas-por-luana-bermudez-e-jorge-bermudez>. Acesso em: 10 ago. 2021.

BERMUDEZ, J. E BERMUDEZ, L. Molnupiravir para Covid- I9: expandindo o acesso ou ampliando a exclusão? CEE/Fiocruz, 28 out. 202 I b. Disponível em: < http://informe.ensp.fiocruz.br/noticias/52382>. Acesso em: 28 out. 2021.

CASAlí, P.; GOLDSChMiT, A. E CETRÁNGOlO, O. Respuestas de corto plazo a la Covid-I9 y desafíos persistentes en los sistemas de salud de América Latina. In: OFICINA DE LA OIT PARA LOS PAÍSES ANDINOS, enero de 202I, Lima, Perú. Disponível em: <www.ilo.org/lima/publicaciones/ WCMS_768040/lang--es/index.htm>. Acesso em: 3 mar. 2021 .

CHAMAS, C. Inovação, propriedade intelectual e acesso a medicamentos e vacinas: o debate internacional na pandemia da Covid- 19. Liinc em Revista, I6(2): e5338, 2020.

CHAMAS, C. Covid-19, Acordo Trips e flexibilidades. Cadernos do Cris/Fiocruz, 10-21, Saúde Global e Diplomacia da Saúde, I-5 jun. 202 I, p. 73-78. Disponível em: <https://portal.fiocruz.br/sites/portal. fiocruz.br/files/documentos/informe_cris_l0-2I_saude_global_e_diplomacia_da_saude.pdf $>$. Acesso em: 16 jun. 2021 .

COLE, J. E DODDS, K. Unhealthy geopolitics: can the response to Covid- 9 reform climate change policy? Bulletin of World Health Organisation, 99: I48-154, 2021.

COVID-19: PESQUISADOR da Fiocruz integra grupo que promove igualdade no acesso à tecnologia. Agência Fiocruz de Notícias, Rio de Janeiro, 16 set. 2021 . Disponível em: <https://agencia.fiocruz.br/ covid- I 9-pesquisador-da-fiocruz-integra-grupo-que-promove-igualdade-no-acesso-tecnologias $>$. Acesso em: 16 set. 202I.

FIORI, J. L. Babel syndrome and the new security doctrine of the United States. Journal of Humanitarian Affairs, I (I): 42-45, 2019. 
FIORI, J. L. Réquiem para uma utopia defunta. Carta Maior, 19 jul. 2020. Disponível em: <www. cartamaior.com.br/?/Editoria/Pelo-Mundo/Requiem-por-uma-utopia-defunda-as-vesperas-daeleicao-americana/6/48192>. Acesso em: 19 jul. 2020.

FURNEAUX, R.; GOLDHILL, O. E DAVIES, M. How Covax failed on its promise to vaccinate the world. The Bureau of Investigative Journalism, 8 out. 2021. Disponível em: <www.thebureauinvestigates. $\mathrm{com} /$ stories/202 I- I 0-08/how-covax-failed-on-its-promise-to-vaccinate-the-world?utm source $=$ Nature + BriefingEutm_campaign $=7885$ e6f72 I - briefing-dy-202 I I $0 \mathrm{I} 2$ Eutm medium $=$ emailEutm_term=0_c9dfd39373-7885e6f72 I-45466566 >. Acesso em: 10 out. $202 \mathrm{I}$.

GLOBAL HEALTH SECURITY INDEX (GHSI). About GHSI-Global Health Security Index. Disponível em: <www.ghsindex.org/about/>. Acesso em: 20 fev. 2021.

GODLEE, F. NHS reorganisation: we don't need a big bang. British Medical Journal, 372: n464, 202 I.

LAFORTUNE, G. How much do we know about countries preparedness to respond to pandemics? Insights from two country-level indices. Sustainable Development Solutions Network (SDSN), 2020. Disponível em: <www.unsdsn.org/how-much-do-we-know-about-countries-preparedness-torespond-to-pandemics-insights-from-two-country-level-indices>. Acesso em: 15 fev. $202 \mathrm{I}$.

LANG, P. Fiocruz é selecionada como hub da OMS para vacina de mRNA. Agência Fiocruz de Notícias, Rio de Janeiro, 21 set. 2021. Disponível em: <https://agencia.fiocruz.br/fiocruz-e-selecionadacomo-hub-da-oms-para-vacina-de-mrna?utm_source=FacebookEutm_medium=FiocruzEutm_ campaign =campaignEutm_term $=$ termEutm_content $=$ content $>$. Acesso em: $2 \mathrm{I}$ set. $202 \mathrm{I}$.

LIMA, M. R. S. \& ALBUQUERQUE, M. Instituições multilaterais e governança global: cenários de reorganização das estruturas de governança global e perspectivas do multilateralismo nas próximas décadas. Rio de Janeiro: Fiocruz, 2021. (Texto para Discussão n. 59). Disponível em: <https:// saudeamanha.fiocruz.br/wp-content/uploads/202 I/05/LIMA-MRS-e-ALBUQUERQUE-M-202 I Institui\%C3\%A7\%C3\%B5es-Multilaterais-Governan\%C3\%A7a-Global-Fiocruz-Saude-AmanhaTD059.pdf>. Acesso em: 4 maio 2021.

LOUIS, M. ¿Para qué sirve la Organización Mundial de la Salud? Entrevista a Auriane Guilbaud, abr. 2020. Disponível em: <https://nuso.org/articulo/para-que-sirve-la-organizacion-mundial-de-lasalud/>. Acesso em: 15 nov. 2020.

MEDICINE PATENT POOL (MPP). Covid-I9 Technology Transfer Hub, 8 out. 202I. Disponível em: $<$ https://medicinespatentpool.org/covid- I 9/technology-transfer-hub/>. Acesso em: 20 out. 2020.

PAI, M. 10 Images that illustrate the shameful global vaccine inequity, 28 ago. 202I. Disponível em: $<$ https://naturemicrobiologycommunity.nature.com/posts/ I 0-images-that-illustrate-the-shamefulglobal-vaccine-inequity >. Acesso em: 30 ago. 2021.

ROBERTS, A. Pandemics and politics. Survival - Global Politics and Strategy, 62(5): 7-40, 2020. Disponível em: <www.tandfonline.com/doi/full/I 0.1 080/00396338.2020.181964I >. Acesso em: 20 out. 2020.

SOJO, A. Pandemia y/o pandemónium: encrucijadas de la salud pública latinoamericana en un mundo global. (Documentos de Trabajo 37). Madrid: Fundación Carolina, 2020. Disponível em: <www. fundacioncarolina.es/wp-content/uploads/2020/I2/DT_FC_37.pdf >. Acesso em: 12 out. 2020. 
OBSERVATÓRIO DE AMÉRICA LATINA E CARIBE (OBSAL) \& INSTITUTO TRICONTINENTAL DE PESQUISA SOCIAL (TRICONTINENTAL). Dossiê n. 30. América Latina sob o coronachoque: crise social, fracasso neoliberal e alternativas populares. São Paulo, Buenos Aires: Instituto Tricontinental de Pesquisa Social, jul. 2020. Disponível em: <www.thetricontinental.org/pt-pt/dossie-30-coronachoque-eamerica-latina/>. Acesso em: 12 out. 2020.

OUR WORLD IN DATA. Statistics and Research. Coronavirus (Covid-19) Vaccinations. Disponível em: $<$ https://ourworldindata.org/covid-vaccinations>. Acesso em: 9 nov. 2021.

USHER, A. D. A beautiful idea: how Covax has fallen short. The Lancet, 397: 2.322-2.325, 202I. Disponível em: <www.thelancet.com/journals/lancet/article/PIISO I 40-6736(2I)0 I367-2/fulltext>. Acesso em: 9 nov. 2021.

WORLD HEALTH ORGANISATION (WHO). Establishment a Covid- 19 mRNA vaccine technology transfer hub to scale up global manufacturing, 16 abr. 202 Ia. Disponível em: <www.who.int/newsroom/articles-detail/establishment-of-a-covid- I 9-mrna-vaccine-technology-transfer-hub-toscale-up-global-manufacturing >. Acesso em: 20 maio 2021.

WORLD HEALTH ORGANISATION (WHO). New ACT-Accelerator strategy calls for US\$ 23.4 billion international investments to solve inequities in global access to Covid- 19 vaccines, tests $\varepsilon$ treatments, 28 out. 202lb. Disponível em: <www.who.int/news/item/28-10-202I-new-act-acceleratorstrategy-calls-investment>. Acesso em: 30 out. 2021 .

WORLD HEALTH ORGANISATION (WHO) \& DALBERG GLOBAL DEVELOPMENT ADVISORS (WHO \& DALBERG). Strategic Review of the ACT-Accelerator-Final Report: An independent report prepared by Dalberg, 8 out. 202I. Disponível em: <www.who.int/publications/m/item/act-accelerator-strategicreview $>$. Acesso em: 15 out. 2021 . 